\title{
Redes sociais, poder e saúde à luz das classes populares numa conjuntura de crise *
}

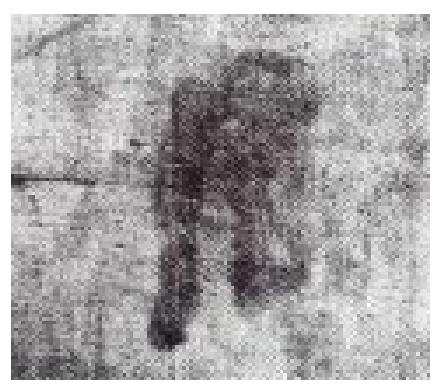

Victor Vincent Valla ${ }^{1}$

VALLA, V. V. Social networks, power and health versus common people in a crisis environment, Interface

Comunicação, Saúde, Educação, v.4 , n.7, p.37-56, 2000.

The process of globalization has driven the State, in its role of provider, into a state of crisis that is affecting the relationship between the lower classes and healthcare services in Brazil. The development of a neo-liberal world, with its concentration of income and its excluding effects, necessarily points toward the construction of another world, in which survival is closely tied to solidarity. Were it not for this crisis, perhaps a proposal of social support in the healthcare area would not draw so much attention. However, once the window is cracked open for the proposal to be examined more carefully, it becomes necessary to acknowledge that it is a legitimate proposal based on its own merits, regardless of the crisis itself. The discussion of social support as a health and education proposal reveals the possibility of approaching an issue that often generates contradiction among the mediators of popular education: the religiosity of the masses. Will this be overcome with time, or is it an integral part of the culture of the masses?

KEY WORDS: Social support; social class; health services accessibility; poverty; religion.

A crise do Estado provedor, provocada pelo processo de globalização, afeta de maneira dramática a relação das classes populares com os serviços de saúde no Brasil. O surgimento de um mundo neo-liberal, concentrador de renda e excludente necessariamente aponta para a construção de um outro mundo, em que a sobrevivência estará íntimamente relacionada com a solidariedade. Se não fosse por essa crise, talvez uma proposta como a do apoio social na área de saúde não chamasse tanto atenção. No entanto, uma vez "aberta a janela" para ver com mais cuidado essa proposta, é possível reconhecer que ela possui legitimidade por seus próprios méritos, e até independe da própria crise. A discussão do apoio social como proposta de educação e saúde abre a perspectiva de abordar uma questão que freqüentemente gera contradições no meio dos mediadores de educação popular: a religiosidade das classes populares. É algo a ser superado com o tempo, ou é parte integrante da cultura popular?

PALAVRAS-CHAVE: Apoio social; classe social; acesso aos serviços de saúde; pobreza; religião.

\footnotetext{
* Apresentado na mesa-redonda "Comunicação e Redes de Poder em Saúde", $2^{\circ}$ Congresso Brasileiro de Ciências Sociais em Saúde, São Paulo, dezembro de 1999.

${ }_{1}^{1}$ Departamento de Endemias Samuel Pessoa, Escola Nacional de Saúde Pública, Fundação Oswaldo Cruz; Faculdade de Educação, Universidade Federal Fluminense; Presidente do Centro de Estudos e Pesquisas da Leopoldina. <valla@ensp.fiocruz.br>
} 


\section{Introdução}

O lugar de onde falo é o da educação popular e saúde e a preocupação central é a das relações entre os mediadores (educadores populares, professores, religiosos, técnicos) e as classes populares. A idéia básica do artigo é que termos como "redes sociais" e "poder" se relacionam mais com as formas com que as classes populares se defendem e como buscam sua sobrevivência diante de quem as domina. Trata-se de uma postura de defesa, e neste sentido as classes populares se preocupam com que a justiça seja feita mais do que alcançarem o poder (Chauí, 1990). Assim, trabalho com a idéia de que as redes sociais das quais as classes populares participam já existem e que o poder que buscam é o de se defender deste capitalismo dito "selvagem" buscando, desta forma, sua "sobre-vida".

A crise de que se fala refere-se à inserção da América Latina no atual processo de mundialização. Stotz (1996) lembra que as empresas transnacionais - em número cada vez menor, em virtude de fusões $e$ incorporações - passaram a impor seus interesses em todos os cantos do planeta, envolvendo questões como o grau de proteção das economias nacionais, o âmbito da intervenção direta do Estado na economia e os limites para o endividamento público em função de gastos sociais. Mas o problema é que os sacrifícios impostos à maioria das populações que vive apenas do seu trabalho não tem a contrapartida de economias em crescimento - pelo menos a taxas compatíveis com as populações e com garantia de melhoria de renda $e$ bem-estar. O mundo do trabalho hoje está constrangido, de um lado, pelo desemprego estrutural e, de outro, pela precarização do trabalho (Valla e Stotz, 1997). Desde a implantação do Plano Real, por exemplo, pelo menos 800.000 empregos já foram perdidos, enquanto 2.500 .000 vagas de trabalho foram eliminadas desde o início dos anos noventa (Rodrigues, 1997).

Em fevereiro deste ano havia 1.474.013 desempregados nas seis maiores regiões metropolitanas do Brasil. Trata-se do maior número de desempregados na história do país (Brafman, 2000). Ao mesmo tempo, a indústria brasileira registrou seu melhor desempenho desde 1997, demonstrando que a melhoria da economia, aos olhos do governo, não necessariamente reflete as condições de vida das classes populares (Clemente, 2000). Mas esse fato traz pouco otimismo, pois não há previsão de o índice de juros cair para estimular o crescimento econômico. Luís Gonzaga Bellusso, da Unicamp, coloca que "essa história de que não dependemos mais de capitais de curto prazo é conversa fiada", pois os juros altos são para atrair mais investimentos de capital estrangeiro especulativo e não para conter a inflação (Ribeiro, 2000). Tão grave é a situação econômica do país que o $1 \%$ mais rico da população detém $13,8 \%$ da renda total, enquanto os $50 \%$ mais pobres, $15,5 \%$ da renda. Ou seja, um rico ganha tanto quanto 50 pobres (Escóssia e Grillo, 2000).

O pagamento da dívida externa já consome $65 \%$ do PIB do país e o governo já começa a gastar as verbas dos projetos sociais para poder cumprir seus "compromissos" com o FMI. O PNUD (Programa das Nações Unidas para o Desenvolvimento) da ONU advertiu o governo brasileiro que não somente são os seus gastos na área social muito aquém do esperado, mas que beneficiam mais as classes médias e os ricos que os pobres (Rossi, 2000). E desde 1998 a

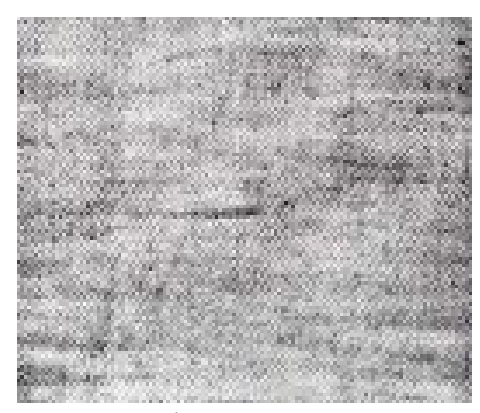

Santo Sudário. A trama 
Caixa Econômica Federal não libera dinheiro do Governo Federal para saneamento básico como forma de cumprir as metas do FMI. Os especialistas em saneamento básico lembram que, num período de três anos, cada dólar gasto em saneamento significa três dólares economizados em saúde. Este ano o Governo Federal cortou em mais de sete bilhões de reais gastos na área social de saúde, educação, assistência e reforma agrária (Pacelli, 2000). A situação nos países em desenvolvimento é muito dramática porque políticas, instituições e serviços voltados para a proteção social - que nunca foram muito eficazes e dificilmente tinham caráter universal - vêm sendo revistos, desmontados ou limitados.

Entretanto a profunda crise daí decorrente deve estimular reflexões $e$ proposições capazes de redimensionar as relações entre o Estado e a sociedade, particularmente para favorecer a ampla maioria dos que se encontram excluídos dos benefícios da riqueza e do bem-estar. Com isso Stotz chama atenção para a necessidade de superar a mera defesa do papel do Estado em prover diretamente ou em regular a oferta privada (contratada ou autônoma) de serviços. Para que tais serviços contemplem de fato as necessidades sociais das populações, precisam levar em conta, obrigatoriamente, o que as pessoas pensam sobre seus próprios problemas e que soluções espontaneamente buscam. (Valla e Stotz, 1997).

Até recentemente, a proposta hegemônica entre aqueles que se preocupam com a qualidade e quantidade dos serviços básicos e, portanto, com o destino do dinheiro público, era a de reivindicação e pressão sobre os governantes (Valla, 1991). Embora se julgue que tal proposta seja correta - e em última instância é como se provoca mudanças no mundo político, ou pelas eleições, ou nas ruas o que se observa em quase toda a América Latina é uma certa perplexidade quanto aos resultados obtidos. O rígido mas contraditório controle fiscal exercido a partir do Governo Federal - seja em atendimento às exigências do Fundo Monetário Internacional, seja em gastos do dinheiro público, como, por exemplo, no pagamento da dívida externa ou na resolução dos apuros dos bancos privados - gera um ambiente de penúria e controle de tal modo que as autoridades contam com estes limites para poder dar pouca atenção às reivindicações dos setores organizados da sociedade civil de caráter popular.

A recente epidemia de cólera no Peru, por exemplo, teve como desfecho uma taxa surpreendentemente baixa de mortalidade, mas muito mais em função da iniciativa dos grupos populares do que em função dos investimentos do governo peruano. Simbolicamente denominado o "duplo caminho", este movimento, de um lado, cobrou do governo o que seria de sua responsabilidade, $e$, de outro lado, quando percebeu que o governo não respondia com os recursos necessários para combater adequadamente a epidemia, implementou uma política própria de mutirão para salvar os atingidos (Valla, 1996).

O sacrifício que está sendo imposto a milhões de pessoas reabre a discussão dos problemas sociais como não sendo questões apenas do Estado. Necessariamente, a formação do mundo neo-liberal excludente, "cria novas mundo, com um novo tipo de consciência social, estimulada pela solidariedade, que se traduz em atos concretos vivenciados pelas pessoas no seu cotidiano" (Genro, 1997, p.3). 
O Estado brasileiro tem capacidade de resolver os problemas de saúde de sua população?

Há uma clara contradição com relação à crise da saúde no Brasil. Embora haja uma nítida queda de qualidade de vida em parte de grandes parcelas das classes populares, uma vasta infra-estrutura de unidades de assistência juntamente com tecnologias como a da terapia de reidratação oral (soro caseiro) fazem com que menos crianças morram antes de completar um ano, e que mais adultos ultrapassem a idade de 65 anos. E, justamente porque as condições de higiene e alimentação são mínimas, é que os problemas conseqüentes de saúde oneram ainda mais os recursos disponíveis para a área de saúde pública. Pois mais pessoas estão sobrevivendo, mas suas condições de vida continuam sendo um problema de saúde. No caso do Brasil, tal quadro é agravado pelos baixos salários e precárias condições de trabalho oferecidos aos profissionais de saúde, dessa forma levando muitos a deixar o serviço público. As longas filas que se formam, tanto nas madrugadas nos centros de saúde, como as de toda hora nos hospitais públicos, criam uma situação em que a "escolha de Sofia" seja um fenômeno freqüente.

Se, de um lado, o acesso ao atendimento seja o problema principal, por outro, a questão da resolutividade é secundarizada. Este dilema entre "eficiência" e "eficácia" na área de saúde tem sua correspondência no das vagas na escola pública e na questão da qualidade do ensino.

É claro que face ao quadro acima descrito é necessário trabalhar para que setores da sociedade civil preocupados com a saúde no Brasil se organizem e demandem mais investimentos dos governantes para contornar a crise. A perplexidade surge, de um lado, da dimensão gigantesca do problema a ser superado; de outro, do reconhecimento do compromisso de "fazer algo", embora a partir de uma sociedade civil debilitada.

Um problema de saúde que atinge milhões de brasileiros, por exemplo, são as múltiplas expressões de saúde mental: cobrindo uma gama de sintomas que vão desde aquilo a que a classe média se refere como "ansiedade" ao que as classes populares chamam de "nervos". Dados recentes de Argentina indicam que mais de $50 \%$ dos medicamentos consumidos pela população são psicofármacos (Bermann, 1995). É de perguntar se, mesmo que o sistema de saúde no Brasil estivesse funcionando satisfatoriamente, seria possível atender todos esses casos adequadamente.

Possivelmente esta sensação de estar "batendo em ponta de faca" seja o sinal de que a discussão chegou a um certo impasse. Não que o fato de reivindicar uma política mais coerente dos governantes não seja necessário, mas que também haja outras dimensões do problema a serem vistas.

Embora seja uma tarefa desagradável, é necessário avaliar a real capacidade do Estado brasileiro em atender aos anseios da população, caso o Estado insista no rumo neo-liberal que vem desenvolvendo desde o início da década de noventa.

Os graves problemas de desemprego e crescente pobreza indicam os limites do sistema de saúde atual. Há um questionamento que se difunde entre profissionais de saúde: se a maneira como o atendimento de saúde se estrutura no Brasil seria capaz de lidar com o que alguns chamam de "sofrimento difuso 
apresentado pelas classes populares". Alguns profissionais estimam que quase $60 \%$ das consultas tratam de problemas psicossomáticos, o tempo necessário para lidar com esses pacientes não se coaduna com a relação eficiência-eficácia (Valla e Siqueira, 1996).

O que está em discussão é a real capacidade de o Estado brasileiro, como se estrutura hoje, satisfazer às demandas que as classes populares vêm apresentando. "Fazer o melhor possível" em cada unidade de saúde do país é certamente importante, mas não necessariamente leva em conta grande parcela da população que não mais se apresenta às unidades de saúde. Também não leva em conta se todas as queixas apresentadas são solucionadas de forma satisfatória (Vasconcelos, 1998).

\section{Apoio social e formas de saúde alternativa}

Inicialmente, o que se propõe é lançar mão de um debate da saúde pública que ocorreu com muito intensidade em setores progressistas nos Estados Unidos na década de oitenta. O debate em torno do que se chama social support, isto é, apoio social, está relacionado com a crise de saúde pública naquele país, mas que foi desenvolvido numa conjuntura diferente da mundialização no Brasil. Neste sentido, propõe-se uma releitura da proposta norte-americana, mas à luz dos aspectos particulares da sociedade brasileira (Valla, 1996).

Apoio social se define como sendo qualquer informação, falada ou não, e/ou auxílio material, oferecidos por grupos e/ou pessoas que se conhecem, que resultam em efeitos emocionais e/ou comportamentos positivos. Trata-se de um processo recíproco, isto é, que tanto gera efeitos positivos para o receptor, como também para quem oferece o apoio permitindo, dessa forma, que ambos tenham mais sentido de controle sobre suas vidas e que desse processo se apreenda que as pessoas necessitam umas das outras (Minkler, 1985). Uma proposta que, embora não fosse uma questão essencial quando o debate foi lançado originalmente, aproxima-se muito da discussão que se trava hoje no Brasil sobre a solidariedade.

Essencialmente, o debate em torno da questão do apoio social se baseia em investigações que apontam para o seu papel na manutenção da saúde, na prevenção contra doenças e como forma de facilitar a convalescença. Uma das premissas principais da teoria é a de que o apoio social exerce efeitos diretos sobre o sistema de imunidade do corpo, isto é, como buffer, no sentido de aumentar a capacidade de as pessoas lidarem com o estresse. Outro possível resultado do apoio social seria sua contribuição geral para a sensação de coerência da vida e do controle sobre a mesma, que, por sua vez, afeta o estado de saúde da pessoa de uma forma benéfica (Cassell, 1976).

Em momentos de muito estresse, o apoio social contribui para manter a saúde das pessoas, pois desempenha uma função mediadora. Assim, permite que as pessoas contornem a possibilidade de adoecer como resultado de determinados acontecimentos, como, por exemplo, a morte de alguém da família, a perda da capacidade de trabalhar, ou um despejo da casa onde se reside por muitos anos.

Cassell levanta a hipótese de que lugares de alta densidade populacional não necessariamente aumentam sua suscetibilidade à doença por causa da 
densidade em si, mas por outras razões. Uma sensação de não poder controlar sua própria vida juntamente com a sensação de isolamento podem ser relacionados com o processo de saúde/doença. A proposta do apoio social sugere que as conseqüências da desorganização social não atingem necessariamente todas as pessoas da mesma forma. Estudos têm demonstrado que os apoios disponíveis de determinadas organizações sociais podem influir beneficamente no sentido de proporcionar fatores de proteção contra o aparecimento de doenças, oferecendo melhorias de saúde física, mental $e$ emocional (Cassell, 1974). Trata-se da noção de empowerment, isto é, um processo pelo qual indivíduos, grupos sociais e organizações passam a ganhar mais controle sobre seus próprios destinos e para quem a vida tem sentido (Minkler, 1985).

Saúde alternativa, religiosidade e classes populares

Embora a proposta de apoio social não seja uma solução para a crise de saúde, foi esta crise que serviu como motivo para que isso fosse discutido. Ao propor a questão do apoio social não se busca apenas uma solução pontual para os chamados "excluídos", mas embutida na proposta está a pergunta se enquanto tal não merece ser considerada também exclusivamente por seus méritos. Neste sentido, serve como uma espécie de trampolim para rever a relação da saúde com a questão médica.

De um lado, o apoio social oferece a possibilidade de realizar a prevenção pela solidariedade e apoio mútuo; de outro, oferece também discussão para os grupos sociais sobre o controle de seu próprio destino e a autonomia das pessoas face à hegemonia médica, por meio da "nova" concepção do homem como uma unidade só (Tognoni, 1991; Valla, 1996).

É neste sentido que a discussão do apoio social, dentro de um contexto de uma relação homem integral e meio ambiente, cabe como questão nos currículos das escolas públicas, nas plataformas dos partidos políticos mais progressistas, nas associações profissionais e de moradores, e nas igrejas. Uma das propostas deste trabalho é relacionar a questão do apoio social com a religiosidade das classes populares.

Bermann (1995) chama a atenção para o efeito ideológico do termo "estresse". Normalmente a discussão deste termo se desenvolve em torno do resultado, e não em torno do processo em si, que é mais importante. Tratar apenas os sintomas transmite a ilusão de que o problema está no mal-estar que a pessoa sente quando procura assistência, desta forma não sendo visto como parte de um processo mais longo que acaba produzindo o mal-estar (Stotz, 1996). Neste sentido, esconde o desgaste do trabalho excessivo a que o trabalhador se submete para não perder o emprego, como também os horários irregulares que impõe o trabalho precário e terceirizado. Quem não tem emprego fixo que se coadune com seus interesses dificilmente escapa do mercado informal e de um "trabalho frustrante". Um trabalho frustrante para as classes populares não significa uma "má escolha", mas quase sempre uma "única escolha" por causa das poucas ofertas no mercado.

Embora não se pretenda negar os processos de estresse que acometeram os membros das classes média e alta, ao mesmo tempo se quer chamar atenção 


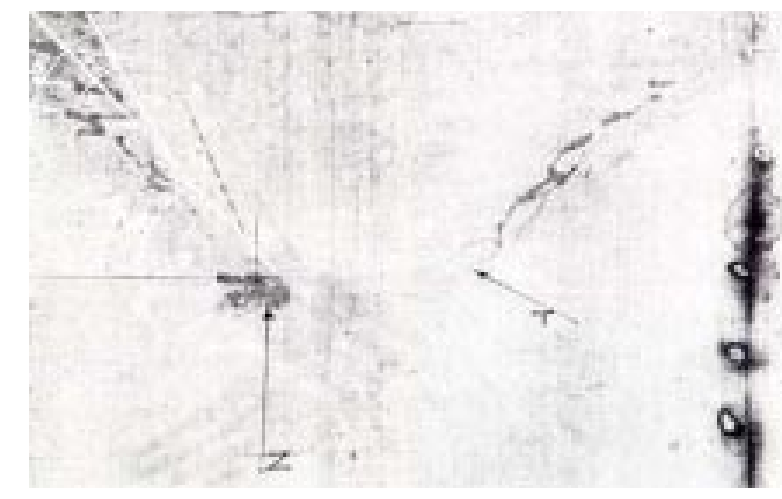

para o fato de que as classes populares nas grandes cidades tendem a sofrer um processo de estresse muito mais intenso. A vereadora Jurema Batista, do Rio de Janeiro, pergunta se há remédio para pressão arterial alta quando o helicóptero da Polícia Militar sobrevoa a favela procurando componentes do narcotráfico. Um engarrafamento no trânsito pode significar pequenas irritações para a classe média, mas para o morador da favela trata-se freqüentemente de uma falta de água contínua ou quedas freqüentes na voltagem $e$ a danificação

Santo Sudário. Geometria da mancha dos eletrodomésticos (McEwen, 1998).

Uma das propostas para o combate ao estresse é a de introspecção $e$ meditação. Embora teoricamente a prática de meditação não seja impossível em qualquer circunstância, certamente um lugar relativamente espaçoso e quieto facilita a concentração. Normalmente o período de meditação mais curto, uma hora, é dividido em duas partes: uma meia hora de ouvir uma leitura para fazer a passagem da rua para a sala de meditação, e uma meia hora de meditação de fato. Uma tarefa difícil para quem trilha o que Chauí (1990) chama o "caminho estreito", isto é, uma vida de pouco dinheiro, espaço e tempo livre.

Num país cujos serviços de saúde são tão moldados pelo modelo biomédico, dificilmente as atividades propostas na área de saúde alternativa são do setor público, desta forma exigindo algum tipo de pagamento (Parker, 1996). Embora não seja impossível que atividades de apoio social sejam desenvolvidas numa unidade de saúde pública - grupos de discussão, relaxamento muscular ou meditação - profissionais de saúde mais críticos afirmam que esse tipo de atividade é vista por muitos colegas como formas de "fugir do trabalho".

O estresse é causado pelo que os profissionais chamam de "superexcitação do organismo" e "carga alostática" é o nome que McEwen (1998) dá ao conjunto de indicadores de estresse. Trata-se de um estilo de vida em que a pessoa está sistematicamente exposta a agressões de ordem física e psíquica. Desta forma, o "susto contínuo" lança grandes quantidades de adrenalina no sangue por um longo período de tempo. Novamente, a causa pode ser a perda de $\mathrm{R} \$ 100.000$ na bolsa de valores, como pode ser a ameaça de uma guerra entre a polícia e os traficantes ou a perda do "barraco" durante a chuva forte. O que importa nessa discussão é que uma grande parcela das classes populares está exposta ao que é chamado "um estado de emergência permanente" (Valla e Stotz, 1996). A grande imprensa tende a definir o termo "emergência" como um acontecimento passageiro - um blecaute ou uma enchente, por exemplo. Uma vez que a água deixe de cobrir os automóveis, ou que a luz elétrica volte, para a grande imprensa terminou a emergência. Mas as condições de vida para muitos moradores de favela indicam esse estado de emergência permanente: distribuição irregular de água, difícil acesso às unidades de saúde, exposição permanente às balas "perdidas" ou ganhar a sobrevivência num mercado informal em processo de saturação.

As recomendações que os médicos fazem sobre uma dieta moderada $e$ prudente como também de exercício físico sistemático esbarram em obstáculos relacionados não somente com as condições de vida das classes populares mas também com questões culturais. De qualquer forma, jogar futebol nos domingos à tarde não parece corresponder à idéia de exercício físico 
sistemático; salve engano, não está muito desenvolvida no Brasil a discussão do que seria uma dieta moderada e prudente para as classes populares, levando em conta os custos e as questões culturais.

Mesmo assim, McEwen (1998) lembra que essas recomendações não são suficientes em muitos casos, se não for possível agir na causa imediata do problema, pois o estresse tem causas sociais complexas, que não podem ser resolvidas pela medicina, como pobreza, más condições de trabalho ou ambiente poluído. McEwen acrescenta que pesquisas mostraram que quanto mais pobre uma pessoa, pior é sua saúde, não importando se ela tem ou não acesso a tratamento médico (McEwen, 1998; Bonalume, 1998).

Laurell (1987) complexifica a categoria de "carga". Com o exemplo da saúde do trabalhador, classifica as cargas em tipos distintos: física, química, biológica, mecânica, fisiológica e psíquica. Quando discute a sobrecarga e subcarga psíquica, refere-se a situações de tensão prolongada; de um lado, a consciência do perigo do trabalho, os altos ritmos do trabalho; de outro, a perda do controle do trabalho por estar subordinado à máquina (Bosi, 1979), a desqualificação do trabalho pela separação de sua concepção e execução e o parcelamento do trabalho que resulta em monotonia e repetitividade. Como se pode ver, condições de trabalho que diferem pouco das condições de vida das classes populares.

Como ser menos competitivo e ansioso como forma de reduzir o estresse num mundo em que as ofertas do trabalho formal estão rapidamente declinando e no qual o mercado informal está se saturando? Assumir uma postura desarmada, franca e aberta se relaciona pouco com uma parcela da população que como forma de sobrevivência emprega uma linguagem permeada do "duplo código", em que o "dizer e desdizer" na mesma frase é um constante (Martins, 1989).

Numa recomendação genérica, Pereira \& Barros (apud Ventura, 1998) chamam atenção para a importância do desabafo e do não "engolir sapos". Essa "aceitação" faz com que o "veneno do corpo" acumulado acabe sendo expulso de outras formas. Mas o que pode significar "engolir sapos" ou desabafar para a maioria das classes populares? Desabafar na hora pode resultar em vários desfechos para as classes populares: pode significar perder o emprego, seja no trabalho da fábrica, seja como empregada doméstica. Numa cultura machista, desabafar na hora, ou seja "não engolir sapo", "não levar desaforo para casa", pode terminar num enfrentamento com fim incerto.

O que parece evidente é que a crise do "acesso aos serviços" é apenas um dos problemas que a população brasileira - e no caso deste trabalho, os pobres enfrenta com relação à saúde. Se a prevenção, o tratamento e a recuperação não são apenas questões do corpo e sim, como propõe a teoria do apoio social, da relação corpo mente, ou, se quiser, corpo alma, é muito provável que a grande procura das camadas populares pelas igrejas hoje signifique mais que refúgio da crise e da desordem.

Para muitos que se dedicam ao tema das classes populares, há uma tendência, ou por formação acadêmica, ou por orientação política, de fazer uma leitura das falas e das ações delas pela categoria de "carência". Se, de um lado, a pobreza e a miséria se prestam a reforçar o uso desta categoria, de outro, há outros intelectuais que pensam que tal leitura possa freqüentemente 
empobrecer suas análises. Chamam atenção para uma outra categoria - a de "intensidade" - que traz dentro de si a idéia de "iniciativa", de "lúdico", da "aventura", de"autonomia" (Saidon, 1991; Almeida, 1995).

José Carlos Rodrigues (1992), exemplificando a idéia de "intensidade", aponta o caso dos "surfistas" dos trens no Rio de Janeiro. Pela categoria "carência", o passageiro estaria em cima do trem, ou por falta de dinheiro, ou porque o trem está lotado. Entrevistas posteriores têm demonstrado que o "surfista" pôde pagar a passagem e que havia vagas no trem escolhido. Carência ou intensidade?

Neste sentido, há de se ter cuidado com a interpretação das ações das classes populares e sua relação com a religião, pois o que pode ser visto como tentativa de resolver exclusivamente um problema material, poderia bem ser o resultado da vontade de viver a vida de maneira mais plenamente possível. Poderia também ser o resultado de procurar uma explicação, um sentido, algo que faz a vida mais coerente - que é justamente uma das propostas do apoio social.

Cabe lembrar que no contexto cultural brasileiro a palavra "comunidade" tem se transformado numa referência às populações pobres, moradores de favelas e de bairros de infraestrutura precária. Mas não é somente a língua que tem modificado o sentido da palavra, também as mudanças sócio-econômicas da vida urbana brasileira, seja pelo crescimento das favelas ao ponto de não comportar uma "comunidade" só, seja pelo grau de violência nesses locais, dessa forma limitando o desenvolvimento de outras organizações populares (Centro de Defesa dos Direitos Humanos Bento Rubião, 1994). É neste sentido que cabe considerar como uma das explicações do extraordinário crescimento da presença das classes populares nas igrejas de todas as religiões, mas principalmente nas chamadas "evangélicas" ou "pentecostais" (Barros e Silva, 1995; Mariz e Machado, 1994). Machado (1996) observa que a falta de apoio institucional nesta época de mudanças sociais intensas faz com que essas igrejas ofereçam um "potencial racionalizador", isto é, um sentido para a vida. Mariz (apud., Machado, 1996, p.30), por sua vez, comenta a frágil presença dos partidos políticos, das associações e do próprio Estado de Bem-Estar entre os pobres e que as religiões oferecem "alguns grupos de suporte alternativos....e criam motivações para resistir à pobreza”.
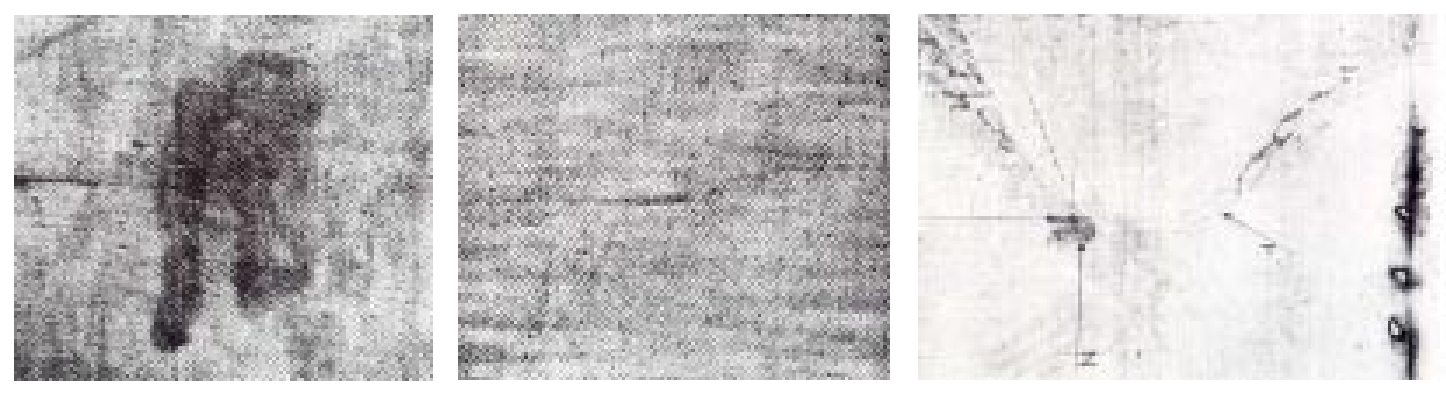

agosto, 2000 
Assim, a busca simultânea de grandes parcelas das classes populares pelo alívio dos seus sofrimentos, mas também a procura da solidariedade e conforto do apoio social mostram que "abaixo da linha-dágua, move-se um vasto conjunto heteróclito de articulações...em contextos de religiosidade e magia que são não-governamentais, sem fins lucrativos, e no entanto, informais..." (Fernandes, 1994, p.28). De um lado, o próprio processo do crescimento da urbanização, juntamente com a conseqüência do aumento das demandas dos bens coletivos $e$ individuais; $e$, de outro, a dilapidação dos direitos sociais $e$ humanos - tudo isso faz com que as "formas tradicionais de ajuda mútua... as reservas de ação social existentes à margem das instituições típicamente modernas" atraiam a atenção dos mais variados setores da sociedade civil (Fernandes, 1994, p.26).

Que alguns líderes religiosos procuram utilizar suas igrejas como forma de se enriquecer ou de angariar votos para seus candidatos - e neste sentido, com a intenção de "manipular" os pobres - não é uma explicação satisfatória de porquê tantos brasileiros estão procurando as igrejas, e, em particular, as evangélicas e pentecostais. Pois, quantos outros grupos no Brasil gostariam de fazer o mesmo com as classes populares, e não conseguem? Há de procurar outra explicação, que relativiza a participação dos líderes religiosos. Possivelmente poderia ser o que Finkler (1985) chama de "símbolos emocionalmente densos que sejam derivados da experiência coletiva daqueles que sofram". Fernandes (1994, p.110-1) cita o estudo do Finkler (1985) sobre os quinhentos centros espíritualistas e cinco milhões de fiéis no México a respeito do sucesso das "curas espírituais... com sofrimentos crônicos de uma forma que a biomedicina não é capaz de igualar....atenuam a dor, quando não eliminam, e ajuda as vítimas do sofrimento a tornar as suas vidas mais toleráveis e significativas". Aqui é possível fazer novamente uma relação com a discussão do apoio social, em que "tornar a vida mais significativa" remete ao "controle sobre seu próprio destino" e ver "mais coerência e sentido em sua própria vida". Cabe perguntar, inclusive, dentro da perspectiva da proposta de apoio social, se as melhorias no estado de saúde desses fiéis não vêm mais do fato de "estarem juntos continuamente no mesmo espaço físico" do que da ação isolada do líder religioso.

Montero (1998) chama atenção para o fato de que a mundialização tem criado uma nova situação para os governos nacionais: muitas decisões tomadas nos níveis ambientais e financeiros não dependem da participação dos governos nacionais. Esse cenário novo faz freqüentemente o papel do cidadão ser reduzido únicamente ao exercicio do voto, diminuindo dessa forma, o interesse pelas eleições. Como consequência, há " $O$ ressurgimento dos poderes locais... (e) a fragmentação do arcabouço jurídico-político dos Estados nacionais", assim resultando em novas maneiras de ver a "soberania popular" $e$ "vontade geral" (Montero, 1998, p.116).

Na sociedade brasileira, cuja formação social não deu lugar à elaboração de um Estado de direito nos moldes clássicos - Estado submetido a leis, no qual o princípio de liberdade reconhecido é o da defesa de interesses definidos em termos da razão... as diferenças culturais.... invés de serem vistas como resquícios de um passado colonial ou obstáculos à modernização democrática, elementos fundamentais de nossa cultura tais como a magia, a possessão 
religiosa, o sentido da comunidade etc. se incorporam pouco a pouco à reflexão do modo particular como se constitui, no Brasil, o espaço público.

(Montero, 1998, p.119)

O que muitos religiosos vêm proclamando por séculos, e o que igrejas como as dos espiritualistas, dos espíritas e dos pentecostais vêm afirmando por algumas décadas, é objeto de investigação científica nas últimas duas ou três décadas em várias partes do mundo. O "efeito placebo", isto é, um efeito benéfico num(a) paciente que sinceramente acredita que uma determinada terapia traz benefícios - de onde vem a noção comum que alguém melhorou depois de ingerir um comprimido de "açúcar" - é um assunto que mais e mais aparece nas revistas científicas. Alguns pesquisadores já levantam a hipótese de que certos ritos afetam os sistemas endócrino e imunológico e que transes e outros estados alterados de consciência têm algo a ver com curas (Eng et al., 1985; Glik, 1988, 1990; Kark et al., 1996; Cox, 1995).

\section{Religião popular e modernização capitalista: uma outra lógica na América Latina}

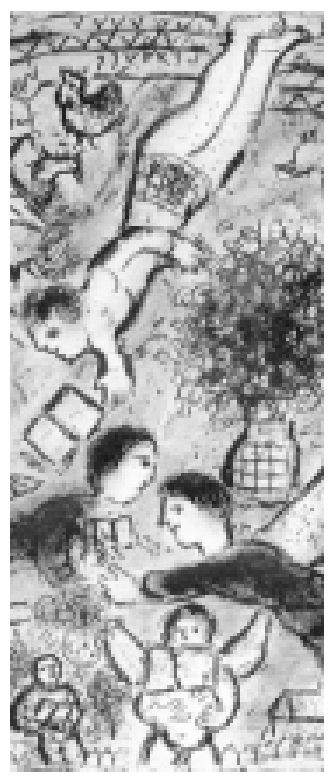

O sub-título é o nome de um estudo desenvolvido pelo sociólogo chileno Cristián Parker (1996), no qual o autor desenvolve uma discussão que levanta novas abordagens em relação àquilo que foi até aqui discutido. Utilizando os primeiros contatos dos indígenas com os colonizadores religiosos espanhóis e portugueses cria um "ato inaugural simbólico" em torno do evento da "conversão". Parker pensa que a conversão ao cristianismo foi possível por um "deslizamento no código de significação correspondente", isto é, uma reinterpretação de seus conteúdos e ritos e imagens sagradas da cultura originária. Parker levanta a hipótese de que as classes populares, de uma forma semelhante, pelo sincretismo, fazem a mesma coisa para "resistir ao perigo de uma desintegração anômica que, em muitos casos... ocorreu levando milhares de índios ao suicídio" (Parker, 1996, p.32; Duviols, 1976, p.32). Utilizando o exemplo da aparição da Nossa Senhora de Guadalupe, Parker demonstra como foi possível às classes populares mexicanas transformar um ato de dominação da igreja mexicana oficial numa devoção em que os pobres enxergaram a santa como sua protetora contra seus dominadores, inclusive os da própria igreja oficial (Parker, 1996).

Atrás dessa forma de ver a importância da religião popular para as classes populares está uma reinterpretação do processo de modernização na América Latina, fruto dos discursos modernizantes sobre o prometido progresso para todos (Parker, 1996). No bojo desta nova interpretação estão os estudos que chamam atenção para a possibilidade de que a "religião popular" seja uma das caraterísticas principais da cultura das classes populares latinoamericanas (Parker, 1996; Beozzo, 1990). Neste sentido, a religião popular pode ser descrita não somente como uma reinterpretação das propostas da religião oficial, mas também como uma forma particular e espontânea de expressar as "necessidades, as angústias, as esperanças e os anseios que não encontram 
resposta adequada na religião oficial... nas expressões religiosas das elites e das classes dominantes" ou até nos partidos políticos progressistas (Parker, 1996, p.55-6).

Nos países de inserção periférica, como é o caso do Brasil, o crescimento veloz do setor de serviços como também do setor da economia informal faz um contraste grande com a introdução e consolidação da tecnologia de informática, que por si mesmo é poupador de mão de obra. Essa lógica global de acumulação, em que prédios luxuosos fazem vizinhança com barracos precários, cria a imagem de um mundo "menos maleável e mais arbitrário" em que as classes populares terão imensas dificuldades de satisfazer suas necessidades básicas (Parker, 1996, p.120-1).

Esse processo de modernização, que inclui em seu interior o de secularização, manifesta-se de forma diferente daqueles que se processaram nos Estados Unidos e na Europa. O processo, que pouco tem a ver com a melhoria das condições de vida dos pobres, resulta no que o Parker denomina uma "transformação da mentalidade religiosa e não tanto uma queda irreversível da fé do povo" (Parker, 1996, p.124). Parker chama atenção para o fato de que essas mudanças são introduzidas na América Latina, num ambiente de extrema desigualdade de condições de vida e de oferta de trabalho e, portanto, não modificam o fato de que o "povo latinoamericano tem um fundo sentido religioso... que forma parte do sentido comum popular" (p.138). Neste sentido, Deus, compreendido como Pai e como Criador, poderoso e benevolente, que cuida e se lembra de seus filhos, "é a realidade mais fundamental da religiosidade popular... é a transmissão de uma experiência vital; mais que a razão da vida, é a força que sustenta" (Parker, 1996, p.139).

Justamente por causa da maneira pela qual o processo de modernização $e$ secularização se implanta na América Latina, aprofundando as desigualdades em vez de garantir um conforto mínimo para a maioria, é que "revitalizam-se a magia e as superstições....que a urbanização subdesenvolvida pode igualmente estar na origem de transformações do campo religioso que...estimula a criatividade religiosa no povo" (Parker, 1996, p.145). Mas ao mesmo tempo é um "elemento de identidade coletiva" que "possibilita a manipulação de eventos ameaçadores, o reforço das energias de sobrevivência, a resistência cultural" (Parker, 1996, p.150; Kudo, 1980, p.69-89).

Na realidade, a discussão que Parker desenvolve sobre a religião popular tem como hipóteses latentes pensar a miséria e a pobreza a que grandes parcelas da sociedade latinoamericana estão sujeitas como momento passageiro, ou considerar este estado de coisas parte do próprio processo de modernização na América Latina.

Neste sentido, a pobreza e miséria a que as classes populares estavam sujeitas

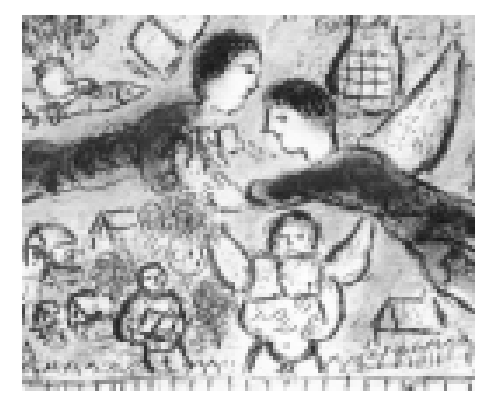
antes do aparecimento do processo de mundialização vêm se agravando depois do reajuste. O intenso incentivo a consumir faz com que se busque uma saída: ou pelo consumo simbólico, seja pela televisão e vídeo, seja pelos jogos ou drogas, seja pelas práticas e ritos mágico-religiosos (Parker, 1996; Evers, 1985).

Embora o sentido religioso forme parte do sentido comum popular, não é de uma forma estática; modifica-se de acordo 


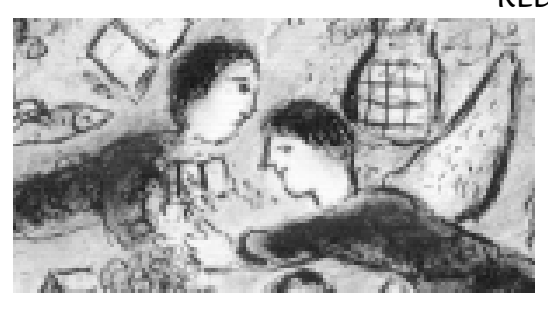

com as circunstâncias históricas. O que se pode afirmar é que certamente não deve ser visto como uma questão tradicional e arcaica (Parker, 1996). Nem se trata de frequentar as igrejas, nem "um simples costume introjetado nos processos de socialização precoce", "mas de uma vivência da providência divina" (p.139-40).

\footnotetext{
...o aspecto religioso é um componente da cultura

e esta deve ser entendida como um fenômeno histórico.

Isto quer dizer que os significados e funções do religioso são relativos às épocas e às situações específicas dos agentes sociais que produzem $e$ reproduzem esse conjunto de sentidos codificados.
}

(Parker, 1996, p.272)

A hipótese de Parker é que as classes populares produzem coletivamente suas representações e práticas simbólico-religiosas, mas que essas manifestações se apresentam de formas diferenciadas, de acordo com sua inserção de classe na sociedade e de acordo com a manifestação religiosa. Essas representações $e$ práticas freqüentemente têm o sentido de um protesto simbólico que, de acordo com a conjuntura, pode não ser visível. São estratégias de sobrevivência de que as classes populares lançam mão dentro de uma sociedade que lhes nega oportunidades de trabalho e seus direitos legítimos (Parker, 1996). De uma forma geral, mas com diferenças, o "catolicismo popular, o pentecostalismo abstencionista, os cultos afro-americanos e o espiritismo supersticiosos", todos apontam para uma "eficácia simbólica" em função das necessidades básicas do presente (Parker, 1996). A fé em Deus e na Virgem Maria oferece um sentido para a vida. O espaço das manifestações (igreja, centro, templo) "garante um âmbito simbólico onde buscar consolo e encontrar energias morais e orientação para enfrentar a incerteza apresentada pela angustiosa situação da fome e da miséria familiar" (Parker, 1996, p.275; Zuluaga, 1985, p.33).

A fome e miséria são tão agudas, que as classes populares freqüentemente vivem no que Parker chama de "imediatismo", "presentismo", em que a busca de uma solução para a subsistência da família é uma forma racional de "adequação à realidade" (Parker, 1996). Como na discussão sobre as categorias de "previsão" e "provisão" (Valla, 1996), não se pensa no futuro (previsão) porque todas as energias estão mobilizadas para evitar a sensação de fome que já havia no passado, e garantir a subsistência no dia de hoje (provisão). A busca da ajuda "sobrenatural", na realidade, é também uma estratégia de sobrevivência.

A fome, o frio, a falta de recursos mínimos, uma vida marcada pela dor, o sofrimento $e$ a violência... elevam os umbrais de incerteza. Tudo isso marca um 
certo encolhimento sobre si mesmo e sobre o núcleo familiar. A promessa à Virgem não supre, mas complementa as ações tendentes a obter o pedaço de pão para os filhos. O ritual-com certo conteúdo mágico- oferece um sentido, tira a angústia, alivia as tensões, possibilita fazer frente à incerteza nessa vida, fortalecendo e revitalizando o indivíduo na busca de soluções concretas para seu problema imediato de fome. Não se busca um benefício compensatório na outra vida... mas uma relação direta com os poderes sobrenaturais... a fim de tornar a vida mais suportável neste mundo. (Parker, 1996, p.83)

\section{Buscando compreender os caminhos das classes populares}

Luz (1996) chama a atenção para a insatisfação de parcelas de todas as camadas sociais do Brasil com os serviços de saúde, sejam eles públicos ou privados. É esta insatisfação que empurra as pessoas a buscar alternativas. Teoricamente, não há nada que impeça que essas próprias alternativas existam no serviço público, mas não é uma questão só de investimento; há a necessidade de ver a relação saúde-doença de outra perspectiva. Tudo isso faz sentido quando nos lembramos que "...as camadas populares mantiveram sobre as questões envolvendo a saúde uma cosmovisão próxima da tradicional, na medida em que... não separam o homem da natureza, o corpo da alma" (Luz, 1996, p.275).

Numa perspectiva de educação popular transformadora, é necessário distinguir entre propostas de saúde alternativa "indivualizantes" das classes média e alta e os caminhos coletivos das classes populares, criados a partir de suas condições de vida.

Certamente os caminhos alternativos percorridos pelas classes populares para aliviar seus problemas de saúde são diversos. Tanto pela questão da relação corpo-mente, quanto pela perspectiva do apoio social, o caminho da espiritualidade e da religião parece apontar como uma das trajetórias principais (Valla, 1998).

A questão apontada acima de "engolir sapos" e/ou de desabafar pode ser uma pista de compreender melhor o "uso" que as classes populares fazem das igrejas, especialmente as igrejas que desenvolvem cultos em que o gritar e o cantar alto são uma constante (Cox, 1995).

Em todos os países do mundo industrializado e em muitos dos países em desenvolvimento - e neste caso o Brasil é um exemplo ímpar - houve uma ênfase na privatização da assistência médica juntamente com sua especialização e tecnificação, resultando numa medicina que busca o lucro em primeiro lugar e é menos humana e mais medicalizada (Cox, 1995; Luz, 1996).

As mais de duas décadas de ditadura militar e inflação elevada trouxeram suas contribuições para que o Brasil seja um país com um dos maiores índices de desigualdade no mundo e que se instalasse a crise de saúde já referida.

Certamente uma das grandes surpresas reservadas à humanidade durante o século $X X$ foi o ressurgimento da religião no mundo inteiro. Coincidência ou não, manifesta-se também na segunda metade do século um desencantamento com o que se conhece como medicina moderna ou "high tech". E neste sentido, começa a voltar à cena uma complementariedade que exisitiu em grande parte da humanidade, que é a da religião com a saúde. 
Se a nossa época é voltada para os fantásticos progressos da pesquisa científica relacionada com a medicina, trata-se também de um curto período da história da humanidade (aproximadamente duzentos anos). Durante a maior parte da longa história da humanidade, no entanto, a magia, a religião e a cura quase sempre andavam juntas (Cox, 1995).

Tudo indica que há vários fatores contribuindo para a volta desta relação religião saúde. A urbanização massiva que vem ocorrendo no planeta, principalmente a partir de imigrações e migrações, se de um lado, inicialmente pode ter tido como uma de suas causas a fascinação pela grande cidade, por outro significa para muitos a perda de um lugar seguro no campo ou no interior e a necessidade de recompor a vida e a identidade (Cox, 1995).

É freqüente que os mediadores progressistas - militantes, profissionais, políticos - demonstrem dificuldades e conflitos com a relação que as classes populares mantêm com a questão religiosa. Se, de um lado, o debate sobre a existência ou não de Deus não parece mais um obstáculo na discussão política, por outro a inclusão da questão religiosa incorpora, com poucas exceções, apenas a proposta da Teologia da Libertação defendida pelas alas progressistas da Igreja Católica. Quando as propostas de outras religiões, tais como as pentecostais ou evangélicos, são abordadas, é freqüente que seja por um prisma de categorias como as de "manipulação" e "alienação".

Mas a dificuldade de compreender o que os membros das chamadas classes populares estão dizendo ou fazendo - por exemplo, no caso das igrejas já referidas - pode bem estar relacionado mais com um problema de postura do que com questões técnicas como, por exemplo, lingüísticas. A questão de postura estaria relacionada com a dificuldade de aceitar que as pessoas "humildes, pobres, moradoras da periferia" são capazes de produzir conhecimento, são capazes de organizar e sistematizar pensamentos sobre a sociedade, e desta forma, fazer opções que apontem para possíveis melhorias para suas vidas.

A compreensão do que está sendo dito também decorre da capacidade de entender quem está falando. Com isso, quer se dizer que dentro das classes populares há uma diversidade de grupos, e a compreensão deste fato passa pela compreensão de suas raízes culturais, seu local de moradia e a relação que mantêm com os grupos que acumulam capital (Martins, 1989).

Na realidade, esta discussão - que certamente não é nova no campo de educação popular - trata das dificuldades dos mediadores de interpretar as classes populares, ou seja, como afirma Martins (1989, p.122), que a "crise de interpretação é nossa".

É necessário que o esforço de compreender as condições e experiências de vida como também a ação política da população seja acompanhado por uma maior clareza de suas representações e visões de mundo. Se não, corre-se o risco de procurar (e não achar) uma suposta identidade, consciência de classe e organização que, na realidade, é uma fantasia de muitos mediadores (Martins, 1989).

Não é nosso desejo, nem nosso incentivo verbal, que garante a suposta unidade das classes populares, mas, sim, a avaliação correta da maneira como 


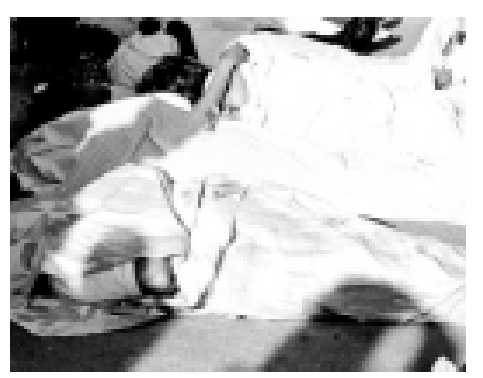

compreendem o mundo. "...a prática de cada classe subalterna e de cada grupo subalterno, desvenda apenas um aspecto essencial do processo do capital.... Há coisas que um camponês, que esta sendo expropriado, pode ver, e que um operário não vê. E vice-versa" (Martins, 1989, p.108). É necessário desfazer a impressão de que o processo histórico anda mais rápido para o operário do que para o trabalhador rural ou morador de favela desempregado.

É possível que um dos grandes problemas para os profissionais, pesquisadores e militantes seja a forma como as classes populares encaram uma vida, existência marcada, cercada de pobreza e sofrimento. É bem provável que estes setores da população tenham uma enorme lucidez sobre sua situação social. Mas clareza de sua situação social pode significar também clareza de que uma melhoria significativa seja uma ilusão. Neste sentido, a crença em melhorias e numa solução mais efetiva pode apenas ser um desejo, embora importante, dos mediadores comprometidos da classe média.

Se a argumentação acima procede, então é possível que a relação que os profissionais estabelecem freqüentemente com a população, acabe sendo de uma cobrança de busca permanente de uma sobrevivência mais racional $e$ eficiente (Chauí, 1990). A frase tão conhecida dos Titãs pode estar indicando, no entanto, um outro enfoque: "A gente não quer só comer. A gente quer prazer para aliviar a dor". Neste sentido, a construção de aparências, que pode ser entendida como a construção de sonhos, não deve ser vista como uma forma apenas de "escapar da realidade", mas pode estar indicando uma concepção mais ampla de vida.

"Prazer para aliviar a dor", então, pode tomar vários sentidos para a população, distintos dos sentidos que têm para a classe média. Certamente, um dos sentidos é o de que vale a pena viver, mesmo dentro de uma perspectiva em que não se pode vislumbrar uma saída no futuro para o sofrimento e a pobreza que se atura diariamente. Se, de um lado, este enfoque pode ajudar a compreender por que seja possível "passar fome para comprar uma TV... o êxtase com o futebol... com o alcoolismo....os jogos de azar" , de outro lado, também ajuda a entender porque "as religiões se oferecem muitas vezes como perspectivas substitutivas (compensação no além... os eleitos do Senhor =consciência substitutiva de elite... acesso a um mundo de protetores, transferência estáctica a um outro cosmo)" (Evers, 1985, p.130).

Satriani (apud Martins, 1989) oferece a ideía de que a cultura popular, para poder se afirmar neste mundo do vencedor, utiliza a duplicidade, o duplo código, "...o afirmar e o negar, o obedecer e o desobedecer" (p.115), "o ajustamento aos valores dominantes e a sua rejeição; interpretações lúcidas combinam-se com ilusões aparentemente alienadas" (Evers, 1985, p. 130); "...um inconformismo profundo... sob a capa do fatalismo" (Chauí, 1990, p.70). Um estilo de vida que "se manifesta na linguagem metafórica, na teatralização que põe na boca do outro o que é palavra do sujeito emudecido" (Martins, 1989, p.115-6).

Martins (1989, p.111) sugere que a cultura popular "deve ser pensada como... conhecimento acumulado, sistematizado, interpretativo e explicativo... teoria imediata". Neste sentido, o aparente absurdo para o profissional pode ter uma lógica clara para a população. 
Finalmente, a idéia da cultura popular como memória da alternativa (Martins, 1989), deveria ser pensada no contexto da dificuldade que uma grande parcela das classes subalternas têm de poder agir somente dentro de um quadro previamente delimitado; tem sentido então "que a mudança só possa ser pensada em termos de milagre (ou seja, de que contém)... a possibilidade de uma outra realidade no interior do existente" (Chauí, 1990, p.79). Isto porque "...o milagre, pedra de toque das religiões populares e de estonteante simplicidade para a alma religiosa é ... inaceitável pelas teologias e apenas de fato por elas tolerado, pois rompe a ordem predeterminada do mundo por um esforço da imaginação" (Chauí, 1990, p.79).

\section{Conclusão}

A crise do Estado provedor, provocada pelo processo de globalização, afeta de maneira dramática a relação das classes populares com os serviços de saúde no Brasil. O surgimento de um mundo neo-liberal, concentrador de renda $e$ excludente necessariamente aponta para a construção de um outro mundo, em que a sobrevivência estará intimamente relacionada com a solidariedade.

Se não fosse por esta crise, talvez uma proposta como a do apoio social na área de saúde não chamasse tanta atenção. No entanto, uma vez "aberta a janela" para ver com mais cuidado essa proposta, é possível reconhecer que ela possui legitimidade por seus próprios méritos, e até independe da própria crise.

A discussão do apoio social como proposta de educação e saúde abre a perspectiva de abordar uma questão que freqüentemente gera contradições no meio dos mediadores de educação popular: a religiosidade das classes populares. É algo a ser superado com o tempo, ou é parte integrante da cultura popular?

Dentro da perspectiva de que as classes populares estão sistematicamente produzindo conhecimento sobre a realidade em que elas vivem, e como conseqüência, fazem uma avaliação dessa mesma realidade, é provável que as dificuldades que alguns mediadores enfrentam com a religiosidade popular esteja relacionada com o que Martins (1989) aponta como "uma crise de compreensão".

A proposta do apoio social, além de oferecer uma contribuição para a crise da saúde no Brasil, é também um instrumento que auxilia os mediadores a decifrarem as várias mensagens que as classes populares estariam produzindo por meio da religiosidade popular.

Embora o termo participação popular seja hoje utilizado universalmente, sua aplicação tem um significado especial para a América Latina. A própria idéia de uma participação "popular" surge, justamente, para se distinguir de uma outra concepção de sociedade, em que quem tem estudo e recursos aponta o caminho "correto" para as classes populares. A ambigüidade do termo não vem somente das várias interpretações que poderiam resultar do seu uso, mas também do fato de que a tradição autoritária da América Latina, e do Brasil, contamina tanto os grupos conservadores, como também freqüentemente os progressistas. Há uma busca de controle das populações que moram nas periferias dos grandes centros e trabalham e moram nas áreas rurais. Controle, com a finalidade de pôr em prática suas concepções de como deve ser a sociedade brasileira. 
ALMEIDA, A.L. Por um tema menor: democracia e participação ativa (o medo e a luta produzindo relações democráticas na escola pública). Niterói, 1995. Dissertação (Mestrado). Faculdade de Educação,

Universidade Federal Fluminense.

BARROS e SILVA, F. Pesquisadora vê democracia religiosa. Folha de São Paulo, São Paulo, 26 dez. 1995. I-6. BEOZZO, J.O. Evangelização e V Centenário. Rev. Eclesiát. Bras., v. 50, n. 199, p.556-617, 1990.

BERMANN, S. Trabajo precario e salud mental. Cordoba: Navajo Editor, 1995.

BONALUME NETO, R. Pesquisa revela "mapa "do estresse. Folha de S. Paulo, São Paulo, 15 de jan. 1998.

Cad.1, p.14-5.

BOSI, E. (Org.) . Simone Weil: a condição operária e outros estudos sobre a opressão. Rio de Janeiro: Paz e Terra, 1979.

BRAFMAN, L. Aumenta crise do emprego. Jornal do Brasil, Rio de Janeiro, 24 mar. 2000.

BRAGA, U. Zero para o saneamento básico. Jornal do Brasil, Rio de Janeiro, 26 mai.2000.

CASSELL, E. J. An epidemiological perspective of psychosocial factors in disease etiology. Am. J. Med., v. 64, p.1040-3, 1974.

CASSEL, E. J. The Healer's Art. New York: J.P. Kippincott Company, 1976.

CHAUÍ, M. Notas sobre cultura popular.In: CHAUÍ, M. Cultura e democracia. São Paulo: Cortez, 1990.

CLEMENTE, I. IBGE confirma a virada da indústria. Folha de São Paulo, São Paulo, 07 abr. 2000. p.2-1.

$\mathrm{COX}, \mathrm{H}$. Fire from heaven: the rise of pentecostal spirituality and the reshaping of religion in the twenty-first century. New York: Addison-Wesley, 1995.

DUVIOLS, P. Religiones y represión em Los Andes em los siglos XVI y XVII. In: JAULIN, R. (Ed.), El etnocidio a través de los Américas. Mensage, n. 396, p. 84-94, 1976.

ENG, E., HATCH, J., CALLAN, A. Institutionalizing social support through the church and into the community. Health Educ. Q., v. 12, p. 81-92, 1985.

ESCÓSSIA, F., GRILLO, C. Rico ganha tanto quanto 50 pobres. Folha de S. Paulo, São Paulo, 29 abr. 2000, p.3-1.

EVERS, T., MULLER-PLANTENBERG, C., SPESSART, S. Movimentos de bairro e Estado: lutas na esfera da reprodução na América Latina. In: MOÍSES, J. Á. (Org.) Cidade, povo e poder. 2. ed. Rio de Janeiro: Paz e Terra, 1985.

FINKLER, K. Spiritualist healers in Mexico: successes and failures of alternative therapeutics. New York: Praeger, 1985.

GENRO, T. Globalitarismo e crise da política. Folha de S. Paulo, São Paulo, 25 mar. 1997. Cad.1, p.3.

GLIK, D. C. Symbolic, ritual and social dynamics of spiritual healing. Soc. Sci. Med., v. 27, p. 1197-206, 1988.

GLIK, D. C. Participation in spiritual healing, religiosity, and mental health. Sociol. Inquiry, v.60, p.158-76, 1990.

GONZALES, J.L. La religión popular en el Perú. Cuzco: Instituto dePastoral Andina, 1987.

KARK, J. D et al. Does religious observance promote health? Mortality in secular vs religious kibbutzim in Israel?

Am. J. Public Health, v. 86, p. 341-6, 1996.

KUDO, T. Práctica religiosa y proyeto histórico II. Lima: CEP, 1980.

LAURELL, A.C. Para el estudio de la salud em su relación com el proceso de producción. In: LAURELL, A.C.

Taller Latinoamericano de Medicina Social. Medellín: Asociacion Latinoamericana de Medicina Social, 1987. p. 61-94.

LUZ, M. T. A arte de curar versus a ciência das doenças. São Paulo: Dynamis, 1996.

MACHADO, M. D. C. Carismáticos e pentecostais: adesão religiosa na esfera familiar. São Paulo: Anpocs/ Editora Autores Associados, 1996.

MARIZ, C. L., MACHADO, M. D. C. Pentecostalismo e a redefinição do feminino. In: LANDIN, L. (Org.)

Pentecostes e nova era: fronteiras, passagens. Rio de Janeiro: Instituto Superior de Religião (ISER), 1994.

(Série Religião e Sociedade, 17/1-2)

54 Interface - Comunic, Saúde, Educ 7 
MARTINS, J. S. Dilemas sobre as classes subalternas na idade da razão. In: MARTINS, J. S. Caminhada no chão da noite: emancipação política e libertação nos movimentos sociais no campo. São Paulo: HUCITEC, 1989.

McEWEN, B.S. Protective and damaging effects of stress mediators. N. Eng. J. Med., v. 338, p. 171-9, 1998.

MINKLER, M. Building supportive ties and sense of community among the inner-city elderly: The Tenderloin Outreach Project. Health Educ. Q., v. 12,p. 303-14, 1985.

MONTERO, P. O problema das diferenças em um mundo global. In: MOREIRA,A.S. (Org.) Sociedade global, culura e religião. Petrópolis: Vozes, 1998: p.113-33.

PACELLI, M. Orçamento sofre corte de 7,5 bi. Jornal do Brasil, Rio de Janeiro, 09 abr. 2000. p.4.

PARKER, C. Religião popular e modernização capitalista: outra lógica na America Latina. Petrópolis: Vozes, 1996.

RIBEIRO, A. Contas externas espantam otimismo. Folha de S. Paulo, São Paulo, 22 abr. 2000. p.21.

RODRIGUES, J. C. Ensaios em antropologia do poder. Rio de Janeiro: Terra Nova, 1992.

RODRIGUES, F. Real já eliminou 755 mil empregos. Folha de S. Paulo, São Paulo, 28 fev. 1997. p. 2-1.

ROSSI, C. ONU sugere mudança no gasto social, Folha de S. Paulo, São Paulo, 05 abr.2000. p.2-11.

SAIDÓN, O. As loucas da Praça de Maio: carência ou intensidade? Tortura Nunca Mais. Bol. Inf. Grupo Tortura Nunca Mais. Rio de Janeiro, v. 3, n.12, 1991.

STOTZ, E.N. A fábrica: saúde e servidão burguesa. In: VALLA,V.V., STOTZ. E.N. Educação, saúde e cidadania. 2. ed. Petrópolis: Vozes, 1996. p. 37-52.

TOGNONI, G. Epidemiologia comunitária. Salud Comunit., Lima, v.1, p.3, 1991.

VALLA, V. V. Investigação científica, assessoria popular e capacitação técnica. In: SPÍNOL, A. W.P. et al. Pesquisa Social em Saúde. São Paulo: Cortez, 1991.

VALLA, V. V. A crise da compreensão é nossa: procurando compreender a fala das classes populares. Educ. Real, v. 22, p.178, 1997.

VALLA, V. V. Apoio social e saúde: buscando compreender a fala das classes populares. In: COSTA, M.V. (Org.) Educação popular hoje. São Paulo: Loyola, 1998. p.151-80.

VALLA, V. V., SIQUEIRA, S.A.V. O centro municipal de saúde e as necessidades de saúde da população trabalhadora. In: VALLA, V. V., STOTZ, E.N. Educação, saúde e cidadania. 2. ed. Petrópolis: Vozes, 1996. p. 87-98.

VALLA, V. V., STOTZ, E. N. Apresentação encontro ou desencontro? In: popular, educação e saúde: teoria e prática. 2.ed. Rio de Janeiro: Relume Dumará, 1997. p.8.

VASCONCELOS, E.M. Educação popular como instrumento de reorientação das estratégias de controle das doenças infecciosas e parasitárias. In: VALLA, V. V. Participação popular e controle de endemias. Cad. Saúde Pública, v.14, supl.2, p.39-58, 1998.

VENTURA, M. Amor protege o coração. Jornal do Brasil, Rio de Janeiro, 21 jan. 1998. p.1-3.

ZULUAGA, F. Religiosidad popular em Colombia. Bogotá: Pontificia Universidad Javeriana, 1985. p.13. (Coleccíon Profesores, 7).

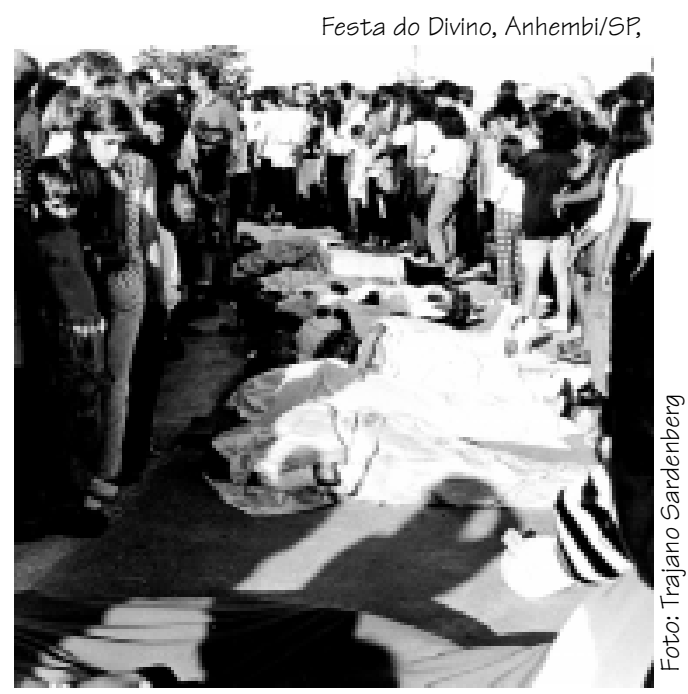

agosto, 2000 


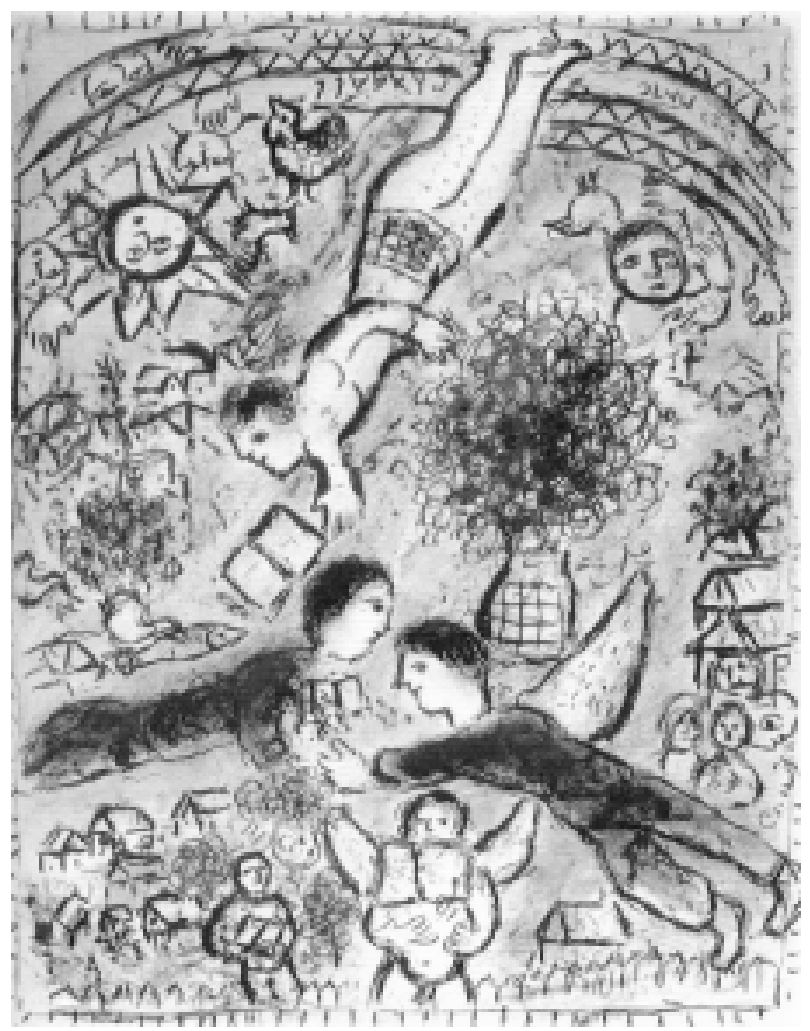

CHAGALL, 0 céu. 1984

VALLA, V. V. Redes sociales, poder y salud según perspectiva de las clases populares en una coyuntura de crisis, Interface _ Comunicação, Saúde, Educação, v.4 , n.7, p.37-56, 2000.

La crisis del Estado proveedor provocada por el proceso de globalización afecta de manera dramática a la relación de las clases populares con los servicios de salud en Brasil. El surgimiento de un mundo neoliberal concentrador de la renta, necesariamente excluidor, apunta hacia la construcción de otro mundo en que la sobrevivencia estará íntimamente relacionada a la solidaridad. Si no fuese por esta crisis, quizá una propuesta como la del apoyo social en el área de la salud no llamase tanto la atención. Sin embargo, una vez "abierta la ventana" para ver con más cuidado tal propuesta, es posible reconocer que posee legitimidad por sus propios méritos e incluso independe de la propia crisis. La discussión del apoyo social como propuesta de educación y salud abre la perspectiva para plantear una cuestión que frecuentemente genera contradicciones entre los mediadores de educación popular: la religiosidad de las clases populares.

PALABRAS-CLAVE: Apoyo social; clase social; aceso a los servicios de la salud; pobreza; religiosidad. 